\title{
A Study of the Impact of Lifestyle on Consumer Purchase Decision of Young Indians
}

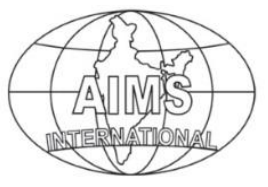

DOI: $10.26573 / 2021.15 .2 .2$

Volume 15, Number 2

May 2021, pp. 89-99

\author{
Kiran L. Maney \\ Jain University \\ Soney Mathews \\ St. Joseph's College of Commerce
}

With India's recent economic growth, there is a growth of a new generation of consumers who give importance to lifestyle. Lifestyle marketing is a procedure of building up connections between items offered in the market and focused on lifestyle gatherings. It includes segmenting the market based on lifestyle dimensions, positioning the products according to the activities, interests and opinions of the target market. This research aims to identify the factors that influence lifestyle and the youth lifestyle that influence the purchase decision. A survey instrument was developed using Likert's scale and data was collected from the college students in the Bangalore city, India. The study's findings revealed that youth purchase products that reflect their lifestyle, and they adopt brand name as a criterion to exhibit their lifestyle at the workplace and social gatherings.

Keywords: Lifestyle, Purchase Decision, Shopping Goods, Decision Making Youth, Consumer Behaviour, Buying Behaviour

\section{Introduction}

Lifestyle is a way of living. It is expressed at the workplace and social gatherings. Lifestyle patterns on an individual and group basis include activities, attitudes, interests, opinions, values, and income allocation. Lazer (1963) conceptualised the lifestyle concept for consumer analysis. Lazer defined lifestyle as a system concept and referred to a distinctive way of living. This concept was quickly adopted in a broader sense of marketing. Plummer, 1974, termed "the more you know and understand about consumers, the more effectively you can communicate and market to them". The term lifestyle gained momentum in research to understand values and lifestyle and became a standard tool in marketing and social science related research across the world (Chu and Lee, 2007). Studies related to lifestyle and consumer behaviour has been done to understand the relationship between lifestyle and consumer behaviour. Lifestyle can be adopted as a segmentation tool, where consumers can be classified based on lifestyle characteristics; each segment is identified with specific characteristics (Kamakura and Wedel, 1995). Harold W. Berkman and Christopher Gilson define lifestyle as "unified" patterns of behaviour that determine and are determined by consumption. The term "unified patterns of behaviour" refers to behaviour in its broadest sense. Attitude formation and such 
internal subjective activities may not be observable, but they are behaviour nonetheless.

Lifestyle is an integrated system of a person's attitudes, values, interests, opinions, and behaviour. A lifestyle that is commonly used to clarify complex consumer buying behaviour. Lifestyle is a way people devote their time and monetary expenditure. Lifestyle segmentation technique has been valuable for advertising planning (Kaynak and Kara, 1996). Lifestyle is the embodiment of the self-concept and is developed by a combination of past experiences, internal characteristics, one's surroundings (Hawkins, Best and Coney, 2000). The study revealed how young people in India live and generate different lifestyle though different ways of living. Lifestyle discovered people's culture, value system and personality. These traits were adopted to express themselves through activities, interests, and opinions (Wells and Prensky, 1996). Lifestyle is a personalised factor which is a resultant of the amalgamated effect of surroundings, culture and social life (Blackwell, Miniard and Engel, 2005).

In India, Krishnan, Jayasree (2011) study on lifestyle, stresses the significance of life and its impact on the buyer's buy conduct. AIO measures were utilised to recognise the way of life measurements of buyers. The investigation affirmed a significant relationship between the way of life of the purchasers and the brands of items utilised. From the examination, it was presumed that buyers regularly pick items, administrations, and exercises over others since they are related to a specific way of life. The items are building squares of a way of life; advertisers should consider these changing ways of life to portion them and position their items effectively.

In India, the way of living is largely influenced by the family, education system, culture, and society. Plenty of research has been carried out to understand the influence of lifestyle on consumer behaviour. India being the fastest growing economy (The Hindu, Dec 2019) in the global market the young Indian trends and the changing lifestyle became great opportunity to marketers and organisations. Adapting and developing products that depict lifestyle of an individual would influence the consumer buying process. Hence, this study therefore highlights on examining the impact of lifestyle of Indian youth during the purchase decision. (Joseph \& Singh, 2013) India has witnessed a huge transformation in the consumer lifestyle, influenced by geo-demographics, socio-cultural factors, psychographics, preferences norms, and behaviour. The Indian consumer today wants to lead a life full of luxury and comfort. Changing prospectus with an "on the go" lifestyle is one of the critical factors for influencing buying behaviour that exhibits a high relevance for formulating marketing strategies. This paper aims to understand the lifestyles (product-oriented, price-oriented and brand-oriented) influence on purchase decision of shopping goods among the Indian youth. The research examines the influence of the lifestyle on the purchase decision. Customers' preference of products is based on product, price and brand of the products.

\section{Methodology}

In this empirical work, questionnaire-based survey was employed to collect the data from Bangalore city. The youth residing in Bangalore is an amalgamation of youth 
from different parts of India. This study includes the youth of the age group $18-37$ years as stated by national youth policy, 2014 and this age group constitutes $27.5 \%$ of India's population. In 2011, census calculated 563 million in the age group of 1838 years. The study included shopping goods (Richard H, 1958), whose functional life exceeds three years. Shopping goods are the products that consumers desire and compare the product, price and brands. The sample collection technique adopted is the multistage random sampling technique, and the data was collected from 977 respondents. A structured and pre-tested questionnaire was adopted as a tool for data collection. All the questions were closed-ended, and five-point Likert-scale was adopted to measure the items, depicted as strongly disagree (1) and strongly agree (5).

The theory of planned behaviour (TPB) (Ajzen \& Fishbein, 1970) defines the relationship between attitudes and behaviour, and this theory is largely used to envisage the customer behaviour based on their attitudes and behavioural intentions. Based on this theory it can be concluded that certain factors influence the behaviour of customers in a certain way during the purchase of products or while deciding to purchase the products. Customers buy products because of its appearance, benefits or components replicate their lifestyle; therefore, there has to be a strong relationship between these product features and lifestyle. Price discounts are widely used sales promotion strategies in offline and online (Dawson \& Kim, 2009). The study (Orth, McDaniel, Shellhammer, \& Loeptcharat, 2004) examined the relationship between consumers' brand preferences, brand image, and lifestyle. Brand image influences consumer behaviour and affects their perception of the brand (Zhang, 2015). Figure 1 represents a proposed model with the core concentration on the youth lifestyle. After examining the related review of the literature on lifestyle and purchase decision, relevant insight was gained. On the basis of the TPB theory and the review of literature the following hypotheses were constructed.

H1: Product-oriented lifestyle has a positive influence on the choice of product.

H2: Price-oriented lifestyle has a positive impact on purchase decision.

H3: Brand-oriented lifestyle is negatively connected with purchase decision.

H4: Lifestyle has a significantly positive influence on the purchase decision.

Figure 1 represents the proposed theoretical model for this research study. This model framework includes the lifestyle construct that comprises a product-oriented lifestyle, price-oriented lifestyle, and brand-oriented lifestyle and consumer purchase decision. The model brings the relationship between lifestyle of youth and purchase decision. The arrows indicate the influence of product, price, and brand oriented lifestyle on the purchase decision.

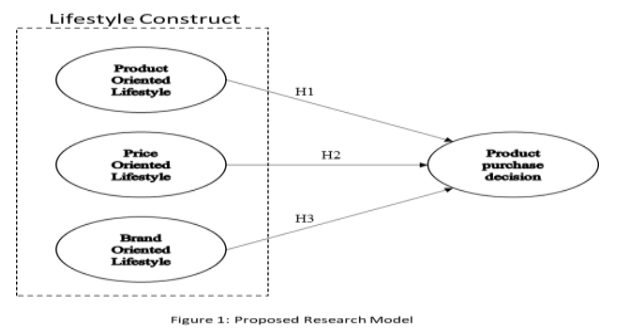




\section{Data Specification}

This study data included 977 usable (1000 distributed) sample data collected from respondents in Bangalore, India. The respondent's demographic profile is represented in Table 1, which includes age, gender, marital status, profession, and family income.

Table 1 Summary of Respondents Profile

\begin{tabular}{|c|c|c|c|}
\hline Demographics & Classification & Frequency & Percentage (\%) \\
\hline \multirow{2}{*}{ Gender } & Male & 422 & 43.2 \\
\hline & Female & 555 & 56.8 \\
\hline \multirow{4}{*}{ Age Group } & $18-22$ years & 305 & 31.2 \\
\hline & $23-27$ years & 273 & 27.9 \\
\hline & $28-32$ years & 229 & 23.4 \\
\hline & 33 - 37 years & 170 & 17.4 \\
\hline \multirow{5}{*}{ Current Profession } & Student & 344 & 35.2 \\
\hline & Studying and Working & 194 & 19.9 \\
\hline & Employed & 338 & 34.6 \\
\hline & Businessman & 67 & 6.9 \\
\hline & Professional & 34 & 3.5 \\
\hline \multirow{2}{*}{ Marital Status } & Married & 345 & 35.3 \\
\hline & Unmarried & 632 & 64.7 \\
\hline \multirow{5}{*}{ Highest Educational qualification attained } & Pre-University & 53 & 5.4 \\
\hline & Diploma & 157 & 16.1 \\
\hline & Undergraduate & 306 & 31.3 \\
\hline & Post-Graduate & 329 & 33.7 \\
\hline & Professional qualification & 132 & 13.5 \\
\hline \multirow{5}{*}{ Family Annual Income } & $<90,000 \mathrm{INR}$ & 11 & 1.1 \\
\hline & 90,001 INR to $2,00,000$ INR & 238 & 24.4 \\
\hline & $2,00,001 \mathrm{INR}$ to $5,00,000 \mathrm{INR}$ & 438 & 44.8 \\
\hline & $5,00,001$ INR to $10,00,000$ INR & 275 & 28.1 \\
\hline & Above $10,00,001 \mathrm{INR}$ & 15 & 1.5 \\
\hline
\end{tabular}

Table 1 shows that 422 Males and 555 Females, representing $43.2 \%$ and $56.8 \%$ of male and female respondents respectively took part in the research survey study. Majority of the respondents are in the age group of $18-22$ years, followed by respondents in the age group of $23-27$ years $(27.9 \%)$, the smallest number of respondents were in the age group 32 to 37 years $(17.4 \%)$. The study showed that a majority $(64.7 \%)$ of respondents were unmarried and $35.3 \%$ were married. In terms of respondents' educational qualification attainment. $5.4 \%$ were PUC, $16.1 \%$ 
diploma holders, $31.3 \%$ undergraduates, $33.7 \%$ have completed their postgraduation and $13.5 \%$ of respondents are professionally qualified. Table 1 also indicates the family income of respondents $1.1 \%$ earned <90,000 INR, $24.4 \%$ earned between 90,001 INR to $2,00,000$ INR, while $44.8 \%$ family income earned between $2,00,001$ INR to 5,00,000 INR, $28.1 \%$ of the respondents earned between $5,00,001$ INR to $10,00,001$ INR the remaining $1.5 \%$ earned above $10,00,001$ INR.

\section{Data Analysis and Discussion}

\section{Structural Model and Hypothesis Testing}

The structural model was confirmed using regression to validate the path (route) coefficients and the effect's dependent and independent variables. Multiple regression was used to test the hypothesis, and the results are presented below.

\subsection{Relationship between Product Features, Lifestyle and Purchase Decision}

H1: Product oriented lifestyle has a positive influence on the choice of product.

Table 2 Showing the Regression Analysis for $\mathrm{HI}$

\begin{tabular}{|l|c|c|c|c|c|}
\hline \multirow{2}{*}{ Model $\left(\mathbf{R}^{\mathbf{2}} \mathbf{0 . 8 1 0}\right)$} & Unstandardised Coefficients & Standardised Coefficients & \multirow{2}{*}{ T } & \multirow{2}{*}{ Sig. } \\
\cline { 2 - 5 } & $\mathrm{B}$ & Std. Error & Beta & & \\
\hline (Constant) & -.071 & .087 & & -.818 & .413 \\
\hline Product Component & .828 & .016 & .806 & 51.309 & .000 \\
\hline Product Benefit & .147 & .020 & .122 & 7.287 & .000 \\
\hline Product Appearance & .083 & .015 & .089 & 5.703 & .000 \\
\hline
\end{tabular}

The $\mathrm{F}$ test of 1385.99 shows that the overall regression is significant. $\mathrm{R}^{2}=0.810$ indicating that the regression-has an equitable fit. The regression analysis shows that the independent variables - product component, product benefit, and product appearance compounding to product-oriented lifestyle positively influence the purchase decision. The results indicate that the product feature dimensions influence lifestyle. Product component $(\mathrm{t}=51.309$, and $\mathrm{sig}=0.000)$, Product benefit $(\mathrm{t}=7.287$, and sig=0.000), and Product appearance ( $\mathrm{t}-5.703$, and sig=0.000) positively influence purchase decision of youth. Table 2 indicates that product component, product benefit and product appearance $(\mathrm{T}=-.818$, sig=0.000) collectively explains 81 percent of variance caused on dependent variable purchase decision due to independent variables compounded by product-oriented lifestyle. The regression equation:

Purchase decision of product-oriented lifestyle $=-.071+.828$ (Product Component) +.147 (Product Benefit) +.083 (Product Appearance).

$$
\mathrm{PD}(\mathrm{PdOL})=-.071+.828 \mathrm{PC}+.147 \mathrm{~PB}+.083 \mathrm{PA}
$$

Product features can have appealing and symbolic value for lifestyle and can communicate benefits verbally to give a quality impression and communicate the lifestyle association. The results indicating product appearance having a positive influence on the lifestyle, can create a unique experience for customers. It can build 
an emotional connect around the features instigating repeated purchases of the same brand. Youth purchase products that can be associated with their lifestyle. Often consumers correlate the features with the quality of the product and can be used as an influential element.

\subsection{Relationship between Price Dimension, Lifestyle, and Purchase Decision}

H2: Price oriented lifestyle has a positive impact on the purchase decision.

Table 3 Showing the Regression Analysis for $\mathrm{H} 2$

\begin{tabular}{|c|c|c|c|c|c|}
\hline \multirow{2}{*}{ Model $\left(\mathbf{R}^{2}=\mathbf{0 . 6 2 5}\right)$} & \multicolumn{3}{|c|}{ Unstandardised Coefficients Standardised Coefficients } & \multirow{2}{*}{$\mathbf{t}$} & \multirow{2}{*}{ Sig. } \\
\hline & B & Std. Error & Beta & & \\
\hline (Constant) & 1.044 & .191 & & 5.480 & .000 \\
\hline Discount Fascinated & -.286 & .031 & -.182 & -9.229 & .000 \\
\hline Payment Easiness Fascinated & 1.060 & .028 & .756 & 38.450 & .000 \\
\hline
\end{tabular}

Note: the dependent variable is Purchase decision where $\mathrm{R}^{2}=0.625, \mathrm{~F}=811.29$, Sig $=0.000$

Table 3 shows the purchase decision related to price lifestyle is positively influenced by price dimensions - price discount and payment easiness. Discount $(\mathrm{t}=-$ 9.229 , sig $=0,000)$ and payment easiness $(\mathrm{t}=38.450$, sig $=0.000)$ are significant factors and influence purchase decision positively.

Price discount offers monetary advantage and an enticement to encourage consumers to purchase the product. The results indicating a positive influence confirm the economic effect of price. The relationship with the lifestyle of young Indian connects to the behaviour of the consumers to search and discover payment easiness modes, and discounts giving a sense of satisfaction and happiness.

The discovery encourages the feeling of achievement, which exhibits their lifestyle. Price-oriented lifestyle is concerned about involvement and how it will add to the experience. The regression equation:

Purchase decision of price-oriented lifestyle $=1.044-0.286$ Price discount $(\mathrm{PD})+$ 1.060Payment easiness (PE)

$$
\mathrm{LS}(\mathrm{POL})=1.044-0.286 \mathrm{PD}+1.060 \mathrm{PE}
$$

\subsection{Relationship between Brand Dimension and Lifestyle}

H3: Brand-oriented lifestyle is negatively connected with purchase decision.

Findings (Table 4) indicates that $\mathrm{R}^{2}=0.447$ has a correlation and a reasonable fit. The overall sig $=0.707>0.05$ shows that the relationship between purchase decision and brand dimensions exists however, the independent variable brand does not negatively influence the choice of brand. Brand image ( $\operatorname{sig}=0.000$ ) shows to have a negative influence on the purchase decision. Rejection of the hypothesis results to acceptance to alternate hypothesis showing that brand has a positive influence on the purchase decision. 
Table 4 Showing the Regression Analysis for $\mathrm{H3}$

\begin{tabular}{|c|c|c|c|c|c|}
\hline \multirow{2}{*}{ Model $\left(R^{2}=0.447\right)$} & \multicolumn{2}{|c|}{ Unstandardised } & \multirow{2}{*}{$\frac{\text { Standardised }}{\text { Beta }}$} & \multirow{2}{*}{$\mathbf{t}$} & \multirow{2}{*}{ Sig. } \\
\hline & $\mathrm{B}$ & Std. Error & & & \\
\hline (Constant) & .087 & .231 & & .376 & .707 \\
\hline Brand Image & .912 & .033 & .668 & 28.021 & .000 \\
\hline Brand Value & .014 & .043 & .008 & .323 & .747 \\
\hline
\end{tabular}

a. Dependent Variable: Purchase decision

Brand image and value may develop an emotional link with lifestyle. Consumers buy brands in alignment with their existing or expected lifestyles confirms the results of a study on Chinese consumers (Wang, Siu, \& Hui, 2004). consumers choose the brand in alliance of the lifestyle to display their lifestyle. Brands are adopted as a means to communicate their way of living. It can be interpreted that the purchase of brands is influenced by the lifestyle.

\subsection{Relationship between the Variable Lifestyle and Purchase Decision}

H4: Lifestyle has a significantly positive influence on the purchase decision.

Table 5 Showing the Regression Analysis for $\mathrm{H} 4$

\begin{tabular}{|l|c|c|c|c|c|}
\hline \multirow{2}{*}{ Model $\left(\mathbf{R}^{\mathbf{2}} \mathbf{= 0 . 6 9 9}\right)$} & \multicolumn{2}{|c|}{ Unstandardised Coefficients } & Standardised Coefficients & \multirow{2}{*}{$\mathbf{t}$} & Sig. \\
\cline { 2 - 6 } & $\mathrm{B}$ & Std. Error & Beta & & \\
\hline (Constant) & 2.536 & .135 & & 18.731 & .000 \\
\hline Product-Oriented Lifestyle & -.306 & .012 & -.491 & -24.962 & .000 \\
\hline Price-Oriented Lifestyle & .160 & .018 & .160 & 9.005 & .000 \\
\hline Brand-Oriented Lifestyle & .511 & .020 & .500 & 25.697 & .000 \\
\hline
\end{tabular}

Table 5 shows lifestyle is a significant factor influencing purchase decision of shopping goods $(\mathrm{t}=18.731$, sig=0.000). The results show that lifestyle positively influences the purchase decision. $\mathrm{R}^{2}=0.699$ shows that the overall regression is significant. All the dimensions of lifestyle (product-oriented lifestyle, price-oriented lifestyle, brand-oriented lifestyle) influence the purchase decision making of the youth.

Purchase decision $(\mathrm{PD})=2.536-0.306$ Product-Oriented Lifestyle $(\mathrm{PdOL})+.160$ Price-Oriented Lifestyle (POL) +.511 Brand-Oriented Lifestyle (BOL) $\mathrm{PD}=2.536-0.306 \mathrm{PdOL}+.160 \mathrm{POL}+.511 \mathrm{BOL}$

Based on the findings, the following segments were developed to understand the relationship between consumer lifestyle and a purchase decision. The proposed model of different lifestyle in relationship with purchase decision is indicated with the results. The results validate the proposed model describing the influence of lifestyle of youth has an influence on purchase decision of youth. 
Product Oriented Lifestyle: A lifestyle segment that revolves around product features including appearance, benefits, and components. The lifestyle includes displaying or exhibiting products at the workplace and home and is considered as pride. The products are chosen or selected based on their lifestyle. A strong involvement with product features characterises youth here. This segment of youth is oriented to buy products that appear and display their lifestyle and prefer to buy products that exhibit their lifestyle.

Price Oriented Lifestyle: A lifestyle segment that includes lifestyle which has an orientation towards price discount and payment easiness mode. Gathering information on price discounts encourages youth to buy the product. Youth are characterised as treasure (discount and payment easiness) hunters. Youth with this lifestyle are choosy in selecting products for purchase and always consider and wait for any discount sales and enjoy buying goods at a discounted price and exhibiting their happiness is their lifestyle.

Brand Oriented Lifestyle: The members of this segment encompass a lifestyle that reflects around brands. The youth lifestyle is characterised as a brand-oriented lifestyle who prefer exhibiting brands at the workplace and social gathering. Youth are more concerned about the brands they purchase and make efforts to display the brand name at a social gathering. Higher brand value is perceived to be a higher brand image.

\section{Conclusions}

The research findings indicated that lifestyle of young Indian has a positive influence on the product purchase decision. The study aims to understand India's existing youth lifestyle from which several theoretical implications can be drawn. The findings can help the marketers expand the vision of marketing strategies and emphasise the impact of several variables while developing promotional strategies that can help enhance the performance of the product in the market and get closer to the consumer. It is evident from the study that consumers give importance to product, price, and brand that associates with their lifestyle; hence the decision on the choice of products reflects their lifestyle. Also, the relationship between the demographics and lifestyle enables the marketer to develop personas of customers and develop products catering to the lifestyle of customers. Consumers choose the brand in the alliance of the lifestyle to display their lifestyle. Brands are adopted as a means to communicate their way of living. It can be interpreted that the purchase of brands is influenced by lifestyle. The results indicating product appearance and lifestyle positively influence the purchase decision; it can create a unique experience for customers who could do the selling. It can build an emotional connect around the features instigating repeated purchases of the same brand.

The relationship with lifestyle relates to the behaviour of the consumers to search and discover payment easiness modes, and discounts giving a sense of satisfaction and happiness. The discovery encourages the feeling of achievement which exhibits their lifestyle. Price-oriented lifestyle is concerned about involvement and how it will add to the experience. The study results can be used to integrate with consumer 
profile and assist the marketer for developing apt marketing strategies. Lifestyle segments behave differently and their characteristics have a great impact on the purchase decision. During the buying process, youth prefer products or brands that possess a unique possibility of imitating their lifestyle. An individual makes the selection of products in order to define their lifestyle. The results conclude the proposed model indicates the influence of lifestyle on the purchase decision of Indian youth. This study provides an area for further research directions in different geographical areas.

\section{References}

1. Adnan, A., Ahmad, A., \& Khan, M. N. (2017). Examining the role of consumer lifestyles on ecological behaviour among young Indian consumers. Young Consumers, 18, 348-377. DOI: https://doi.org/10.1108/ YC-05-2017-00699

2. Ajzen, I. \& Fishbein, M. (1970). The prediction of behaviour from attitudinal and normative variables. Journal of Experimental Social Psychology, G, 466487.

3. Anitha, N., (2016). "Influence of lifestyle on consumer decision making with special reference to organised retail formats in Chennai". Indian Journal of Commerce \& Management Studies. Volume VII (1)

4. Ashraf, M., \& Khan, K. M. (2016). Adolescents' role in family decision making for services in India. Young Consumers, 17(4), 388-403.

5. Atchariyachanvanich, K., \& Okada, H. (2007, June). How Consumer Lifestyles Affect Purchasing Behaviour: Evidence from Internet Shopping in Japan. Journal of Entrepreneurship Research, 2(2), 63-78.

6. Blackwell, R. D., Miniard, P. W., \& Engle, J. F. (2005). Consumer behaviour. Cincinnati: South-Western College Publishing.

7. Chu, Y. and Lee, J.J. (2007), "The experiential preferences of the online consumers in different Internet shopping lifestyles towards online shopping web sites", Human-Computer Interaction. HCI Applications and Services, Lecture Notes in Computer Science, Vol. 4553, Springer, Berlin, pp. 3-11.

8. Dawson, D. J. (1985). Retail research: studies in 'lifestyle. Retail and Distribution Management, 13(5), 38-39.

9. Dawson, Sandy and Kim, Minjeong, "External and internal trigger cues of impulse buying online", Direct Marketing: An International Journal, 3 (1). 20 34. 2009.

10. Gordon R, F. (1980). The Logic of Price Decision-Making. Management Decision, 18(5), 235-245. Retrieved from https://doi.org/10.1108/eb001243

11. Gunter, B., \& Furnham, A. (1992). Consumer Profiles: An Introduction to Psychographics. London: Routledge.

12. Joseph, S., \& Singh, V. (2013). Changing Lifestyles Influencing Indian Consumers: Conceptualising and Identifying Future Directions. Global Journal of Management and business Studies, 3(8), 861-866.

13. Kaynak, E. and Kara, A. (1996) Consumer lifestyle and ethnocentrism: a comparative study in Kyrgyzstan and Azarbaijan. In U. Schoeneberg (ed.), 49th Esomar Congress Proceedings. Istanbul/Amsterdam: ESOMAR, pp. 577-96. 
14. Keller, K.L. (2003), "Brand synthesis: The multidimensionality of brand knowledge", Journal of Consumer Research, Vol. 29 No. 4, pp. 595-600

15. Kamakura, W.A. and Wedel, M. (1995) Lifestyle segmentation with tailored interviewing. Journal of Marketing Research 32(3), 308-17.

16. Kotler, P. (1999). Marketing Management: Analysis, Planning, Implementation and Control. New Delhi: Prentice Hall of India Pvt. Ltd.

17. Kotler, P., \& Amstrong, G. (2007). Principles of Marketing. NJ: Prentice Hall International, Englewood Cliffs.

18. Krishnan, J. (2011). Lifestyle - A Tool for Understanding Buyer Behaviour. Int. Journal of Economics and Management, 5(1), 283-298.

19. Kucukemiroglu, O. (1999), "Market segmentation by using consumer lifestyle dimensions and ethnocentrism: an empirical study", European Journal of Marketing, Vol. 33 Nos 5/6, pp. 470-87.

20. Kucukemiroglu, O., Harcar, T. and Spillan, J.E. (2006), "Market segmentation by exploring buyer lifestyle dimensions and ethnocentrism among Vietnamese consumers: an empirical study", Journal of Asia-Pacific Business, Vol. 7 No. 4 , pp. 55-76.

21. Lazar, Anderson Thomas (1963). Lifestyle and psychographics: a critical review and recommendation, Advances in Consumer Research, Vol. 11.

22. Likert, R. (1932). A technique for the measurement of attitudes. Archives of Psychology, 140, 5-55.

23. Ma, F. (2004). Lifestyle Segmentation of the Chinese Consumer. Sinomonitor International. China: World Association of Research Professionals.

24. Mitchell, A. (1983). The Nine American Lifestyles. New York: Macmillan Publishing Company.

25. Moore, C. M., \& Birtwistle. G. (2004). The Burberry business model: creating an international luxury fashion brand. International Journal of Retail \& Distribution Management, 412 - 422.

26. Plummer, J.T. (1974), "The concept and application of life style segmentation", Journal of Marketing, Vol. 38 No. 1, pp. 33-7.

27. Orth, U. R., McDaniel, M., Shellhammer, T., \& Loeptcharat, K. (2004). Promoting brand benefits: the role of consumer psychographics and lifestyle. Journal of Consumer Marketing, 21(2), 97-108.

28. Richard H, H. (1958). The Distinction between Convenience Goods, Shopping Goods, and Specialty Goods. Journal of Marketing, 23, 53-56. doi:10.2307/1248017

29. Soney, M., \& Nagaraj H. An (2010). Analytical Study of VALS of Youth Implication to Marketers. 1(1), $20-23$.

30. Wells, W., \& Tigert, D. (1977). 'Activities, interests, and opinions". Journal of Advertising Research, 27-35.

31. Wells, W.D, and Prensky, D. (1996), Consumer Behaviour, John Wiley \& Sons, NY, pp 44-6.

32. Yang, K. (2004). A comparison of attitudes towards Internet advertising among lifestyle segments in Taiwan. Journal of Marketing Communications, 195-212. 
33. Yousaf, S., \& Malik, M. S. (2013). Evaluating the influences of religiosity and product involvement level on the consumers. Journal of Islamic Marketing, 4(2), 163-186.

34. Yoon, E., \& Kijewski, V. (1997). Dynamics of the relationship between product features, quality evaluation, and pricing. Pricing Strategy and Practice, 5(2), 4560. Doi: https://doi.org/10.1108/09684909710163601

35. Zaichkowsky, J. L. (1985). Measuring the involvement construct. Journal of Consumer Research, 12, 341352.

36. Zhang, R. (2015). Internet dependence in Chinese high school students: Relationship with sex, self-esteem, and social support. Psychological Reports, 117(1), 8-25. doi:10.2466/18.21.PR0.117c11z0

37. https://www.thehindubusinessline.com/economy/harvard-india-will-be-worldsfastest-growing-economy-in-coming-decade/article23776487.ece

\section{About Our Authors}

Kiran L Maney Assistant Professor, Center for Management Studies, Jain (Deemed-to-be) University, Bangalore. Assistant Professor in the field of Marketing at Center for Management Studies, Jain (Deemed-to-be) University. Worked in esteemed organizations like Onida Savak and Featherlite. Started her own venture in interiors and currently working as business partner and consultant to Novo Tree Minds Consulting Pvt Ltd and Mark Enterprises. Mentor and Consultant for Startup's. She graduated with B.Sc. (PCM) from Karnataka University, Dharwad. Completed her Post graduation in Management from Karnataka University, Dharwad. She is currently pursing PhD in the field of Lifestyle Marketing. Having completed Chartered Institute of Marketing, UK Level 4 - Marketing and Integrated Communication is currently a tutor for students pursing CIM.

Soney Mathews PhD (Commerce), M. Com., M. Phil., B.Ed., M.M.M., CIM (UK), MSc Applied Psychology Associate Professor at St. Joseph's College of Commerce. She has a brilliant pedagogy which spreads over a span of 24 years of teaching and research in the areas of Marketing and General Management. During her tenure of teaching, she has taught both Post-Graduate and Graduate students from both the International and National platforms. She was associated with teaching students from various universities like Latrobe University-Australia, University of HertfordshireUK, Laureate International Universities-USA, INTI-International UniversitiesMalaysia, University of Wollongong, Bangalore University and Jain UniversityBangalore. Keeping research as a focus and interest area, she has published various research papers in academic journals both international and national with high impact factor in the areas of Marketing Management and General Management. She is also a research supervisor for Ph.D. and M. Phil. candidates in the field of commerce and management. 